\title{
CREEP SHEAR DEFORMATION OF GLUED-LAMINATED BAMBOO
}

\author{
${ }^{*}$ Ngudiyono $^{1,2}$, Bambang Suhendro ${ }^{1}$, Ali Awaludin ${ }^{1}$ and Andreas Triwiyono ${ }^{1}$ \\ ${ }^{1}$ Departement of Civil and Environmental Engineering, Faculty of Engineering, Gadjah Mada University, \\ Yogyakarta, Indonesia \\ ${ }^{2}$ Departement of Civil Engineering, Faculty of Engineering, Mataram University, Mataram, Indonesia
}

*Corresponding Author, Received: 31 March 2020, Revised: 14 April 2020, Accepted: 28 April 2020

\begin{abstract}
Glued-laminated bamboo has been applied to many parts of building structures. In peripheral, edge beams part of the multi-storey buildings and beams supporting canopy slabs, are not only subjected to bending moment but also to a shear load. Glued-laminated bamboo is classified as a viscoelastic material since it shows the properties which are common to both solid and fluid. In the long-term constant or steady loading, the glued-laminated bamboo will cause creep deformation. This paper discussed the experimental investigation of the creep behavior of glued-laminated bamboo subjected to pure shear. The specimens were apllied constant load with the different load level $20 \%, 30 \% 40 \%$ of the ultimate shear capacity. The instantaneous or elastic deformation was recorded after 1 minute a constant load was applied, then the load was maintained for 180 days. An intensive recording was done every 5 minutes for 60 minutes (1 hour), every 60 minutes (1 hour) until 300 minutes (5 hours), then every day until 90 days, every 1 month until 180 days. The results showed that creep shear deformation, strain and rate depend on load level. Creep shear deformation, strain and rate increased when the load level increased. The Burger and Power law model were used to fit the creep data and then can be used for predicting primary and secondary creep stage. The models were successfully for predicting viscoelastic creep shear parameters.
\end{abstract}

Keywords: Glued-laminated bamboo, Creep shear, Burger model, Power law, Creep shear parameters

\section{INTRODUCTION}

Bamboo has been used widely long time ago as a substitute for wood/timber building materials, because it has many advantages i.e. it is categorized as fast-growing plant (harvest in 3-4 years), eco-friendly, high strength/weight ratio, renewable and sustainable material and it has similar environmental characteristics and comparable physical and mechanical properties with wood/timber [1-6]. Bamboo in its natural form is a hollow tubular structure [7], which gives high efficiency in resisting bending forces. However, its natural structure is also the largest impediment to its use because of the difficulty in making connections $[6,8]$. By using laminated technology, the rectangular elements of bamboo glued together will produce new material called glued-laminated bamboo [9-11].

In recent years, the glued-laminated bamboo has been applied to many parts of building structures. In peripheral, edge beams part of the multi-storey buildings and beams supporting canopy slabs are not only subjected to bending moment but also to a shear load. Glued-laminated bamboo is classified as a viscoelastic material since it shows the properties which are common to both solid and fluid. In the long-term constant or steady loading, the glued-laminated bamboo will cause creep deformation. The phenomenon of creep deformation, particularly in anisotropic or orthotropic materials is critical to structural design. For example, permanent creep deflection on beams can influence the serviceability of structures. Another issues due to creep deformation is the ability to change the material characteristics and mechanical properties of the structural elements, moreover, will cause the collapse of a building structure [12-14].

Research on creep bamboo, bamboo composite, glued-laminated bamboo has been carried out by previous reseachers [10-12,15-19], but they focused more on flexural creep. Furthermore, Ounjaijom and Rangsri, 2016 [20] conducted an experimental and numerical study of compression creep of bamboo in the transverse direction to determine the effect of vascular bundles on creeprecovery behavior. More detailed research on compressive and tension creep of glued-laminated bamboo (glubam) was carried out by Li and Xiao, 2015 [11], the creep parameters of the research results were used to validate the creep deformation of the flexural glued-laminated bamboo beam reinforced with CFRP on the bridge model. However, the research creep shear behavior of glued-laminated bamboo has not been fully 
investigated

This paper presents the experimental investigation and modelling of the creep behavior of glued-laminated bamboo subjected to pure shear. Additionally, the mechanical and power model were used to estimate the creep shear parameters.

\section{CREEP MODELLING}

\subsection{Burger Model}

The modelling of creep can be used as mechanical model to visualize the stress and strain relationship of the viscoelastic material due to the constant applied load within a certain time. This model used linear elastic spring to idealize linear elastic solid and linear viscous dashpot to idealize viscous fluid [21-22].

There are a few varieties of the constitutive equation of viscoelastic linear material depending on combination number of the spring and the dashpot elements. For instance, Maxwell and Kelvin model are adequate for qualitative and conceptual analysis, but generally weak for the quantitative representation of the behavior real materials. In order to improve the representation, therefore user needs to increase the number of elements by combining a number of springs and dashpots.

The mechanical model that effectively describes the time dependent behavior of viscoelastic material such as timber, wood, bamboo, composite, glued-laminated bamboo, etc. under constant relative humidity and temperature for a short period are four-element model or Burger model illustrated in Fig. 1, where the Maxwell and Kelvin model are connected in series. The constitutive equation can be derived by considering the shear strain response under constant applied loading. The total shear strain at the time was obtained by summing the shear strain on four elements given by the Eq. (1), where: $\gamma(\mathrm{t})$ : shear strain at time $t, \tau$ : constant applied load, $\mathrm{G}_{1}$ : shear elasticity of element spring Maxwell, $\mathrm{G}_{2}$ : shear elasticity of element spring Kelvin, $\eta_{1}$ : viscosity of element dashpot Maxwell, $\eta_{2}$ : viscosity of element dashpot Kelvin. The first term on the right-hand side of the Eq. (1) represents instantaneous deformation, the second term describes delayed elasticity and the third term is the plastic flow component. So, the first term describes the elastic behavior while the combination of the second and third terms accounts for the viscoelastic or creep behavior. It should be noticed that the Burger model is valid only for primary and secondary stage of creep behavior. The typical creep curve of Burger model shown in Fig. 2.

$$
\tau(\mathrm{t})=\frac{\tau}{\mathrm{G}_{1}}+\frac{\tau}{\mathrm{G}_{2}}\left(1-\mathrm{e}^{-\left(\mathrm{G}_{2} / \eta_{2}\right) \mathrm{t}}\right)+\frac{\tau}{\eta_{1}} \mathrm{t}
$$

can be rewritten as,

$$
\gamma(\mathrm{t})=\beta_{1}+\beta_{2}\left(1-\mathrm{e}^{-\beta_{3} \mathrm{t}}\right)+\beta_{4} \mathrm{t}
$$

where, $\quad \beta_{1}=\tau / G_{1}, \quad \beta_{2}=\tau / G_{2}, \quad \beta_{3}=G_{2} / \eta_{2}$, and $\beta_{4}=\tau / \eta_{1}$ are unknown parameters to be estimated. The Eq. (2) can solved simultaneously using nonlinier curve fitting of the creep data test.

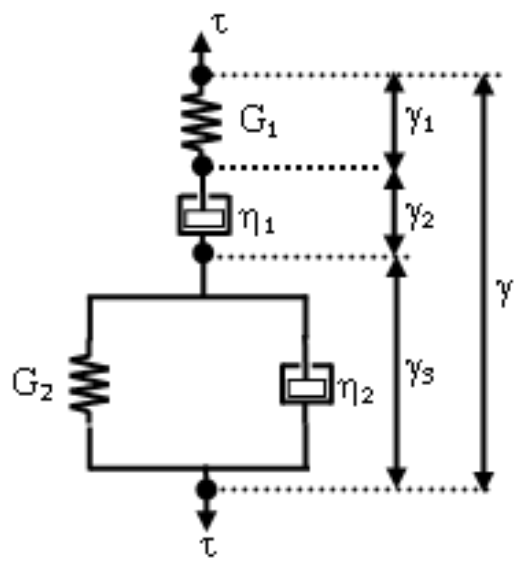

Fig.1 Burger model [21-22]

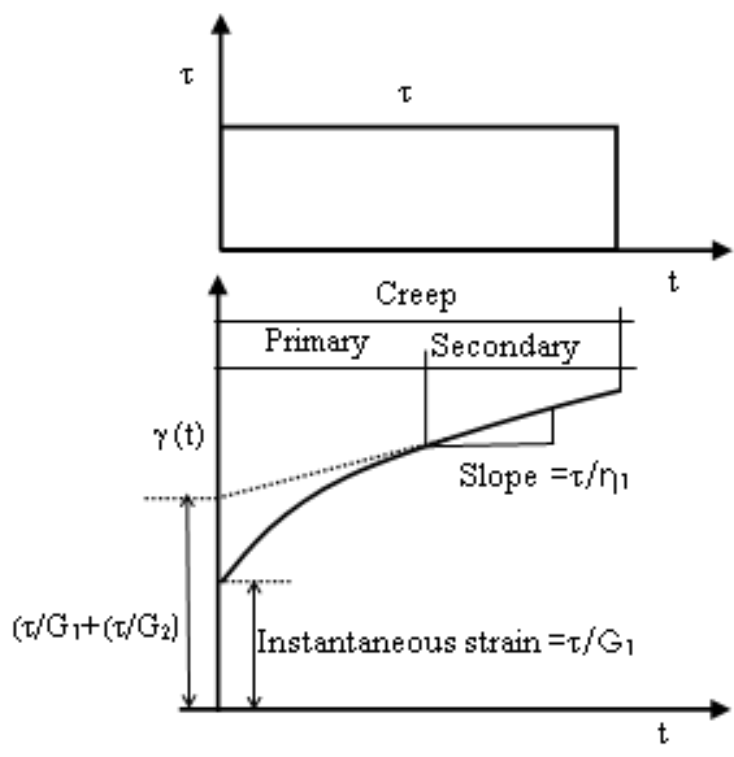

Fig.2 Typical creep curve of Burger model [21-22]

\subsection{Power Law}

The creep shear behavior of glued-laminated bamboo can also be modeled using the Power Law model which includes two factors i.e. constant applied load $(\tau)$ and time $(t)$. The Power Law 
approach is more effective than the mechancal model (such as Maxwell, Kelvin, Burger, and others). The power law function is suitable to discribe nonlinear behavior. Generaly, the Power Law equation is expressed in the rate of creep $(\&$ cr $)$ as follows [21,25],

$\&_{c r}=A \tau^{n} t^{m}$

If Eq. (2) is integrated with time (t), then the creep strain $\left(\gamma_{\mathrm{cr}}\right)$ is,

$$
\gamma_{\mathrm{cr}}=\frac{\mathrm{A}}{\mathrm{m}+1} \tau^{\mathrm{n}} \mathrm{t}^{\mathrm{m}+1}
$$

where $\mathrm{A}, \mathrm{n}$, and $\mathrm{m}$ creep parameters can be obtained from the curve fitting of the creep shear test experimental data. The value of $\mathrm{A}, \mathrm{n}$ greater than 0 and the value $m$ more than -1 and less than or equal to 0 .

\section{METHODOLOGY}

\subsection{Materials}

Three to four-year-old Dendrocalamus asper bamboo species used in this study, for the production of glued-laminated bamboo specimens. The bamboo culm was preserved with a $5 \%$ borax liquid and then naturally dried until the moisture content (MC) was approximately 12\% using conventional drying. Then, the bamboo culm was cut $1.5 \mathrm{~m}$ and splitting producing strips with cross section of $20 \mathrm{~mm}$ widths and about $10-15 \mathrm{~mm}$ thick (according to the thickness of the bamboo culm) and then planned until the final dimension of strips bamboo was $15 \mathrm{~mm}$ of width and $5 \mathrm{~mm}$ of thickness.

The strips of bamboo were laminated together by using Polyvinyl Acetate (PVA) into beams with rectangular cross-section and then a hydraulic jack pressure of $2 \mathrm{MPa}$ was applied for minimum 6 hours. The beams were left to cure for one week, after which the formwork and pressure was removed. The finishing process was carried out to obtain dimension of glued-laminated bamboo beams 100 mm x 200 mm x1000 mm. Furthermore, the specimens for creep shear deformation test were made by cutting the beams into gluedlaminated bamboo board with a size of $20 \mathrm{~mm} \mathrm{x}$ $100 \mathrm{~mm}$ x $200 \mathrm{~mm}$ as shown in Fig. 3. The size of the test specimen was determined according to the stress distribution (as shown in Figure 4) by using finite element analysis (FEA) ABAQUS software [25]. From Fig. 4, it can be seen that the shear stress $\left(\mathrm{S}_{12}\right)$ was more dominant then the principle stresses in $1\left(\mathrm{~S}_{11}\right)$ and $2\left(\mathrm{~S}_{22}\right)$ direction.

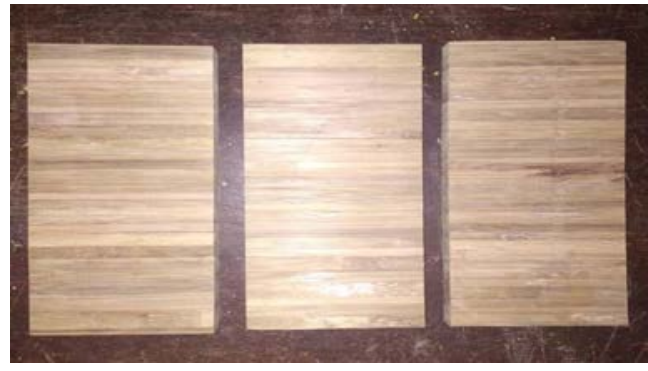

Fig.3 Specimens creep shear test of gluedlaminated bamboo

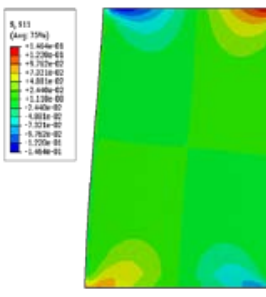

(a)

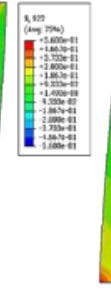

(b)

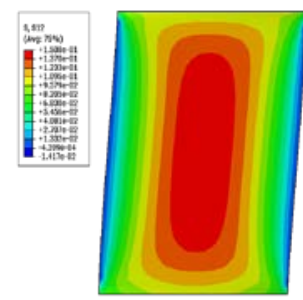

(c)

Fig.4 Stress distribution of specimen (a) $S_{11}$ (b) $\mathrm{S}_{22}$ (c) $\mathrm{S}_{12}$

\subsection{Creep Test Procedure}

Creep shear deformation test was according to the previous studies conducted by Guo, Chen and Liou, 2007 [23], then the modification device was carried out. The purpose of this test was to determine the creep shear behavior of gluedlaminated bamboo. Creep shear deformation test set-up is as shown in Fig. 5.

The Temperature (T) and Relative Humidity (RH) room was kept at range $28 \pm 3^{\circ} \mathrm{C}$ and $72 \pm 5 \%$ using a microcontroller connected to a humidifier, dehumidifier, and relative humidity sensor. Meanwhile, the temperature was kept automatically using Air Conditioner (AC). The Relative Humidity (RH) and temperature was recorded by using Elitech RC-4HA/C Mini Temperature and Humidity Data Logger. The result can be seen in Fig. 6 .

The specimens were placed in the creep shear test equipment, the bottom was given fixed as high as $50 \mathrm{~mm}$ to avoid vertical and horizontal deformation and in the top end of $50 \mathrm{~mm}$ a clamp was attached to connect the wire and the load, and 
the upper end of the specimens were mounted in a roller support to prevent vertical deformation. However, horizontal deformation can still occur.

The horizontal deformation was measured by using dial gauge with an accuracy of 0.01 . The constant load levels applied were $20 \%$, 30\%, and $40 \%$ to ultimate shear capacity, using concrete blocks. The result of short term shear deformation capacity test showed that the shear ultimate capacity deformation of glued-laminated bamboo specimens was $1000 \mathrm{~N}$ with shear modulus elasticity $17.167 \mathrm{MPa}$, so that each load levels was $200 \mathrm{~N}, 300 \mathrm{~N}$ and $400 \mathrm{~N}$ respectively. At the bottom, the concrete block was supported with a hydraulic jack before loading was applied. Furthermore, constant loading was applied by releasing the hydraulic jack slowly until the load was working.

According to the ASTM D6815 [24], instantaneous or elastic deformation was recorded after 1 minute a constant load was applied, then the load was maintained for 180 days. An intensive recording was done every 5 minutes for 60 minutes (1 hour), every 60 minutes (1 hour) until 300 minutes (5 hours), then every day until 90 days, every 1 month until 180 days. The creep strain was determined by subtracting horizontal deformation data with high of the shear region specimen (100 mm).

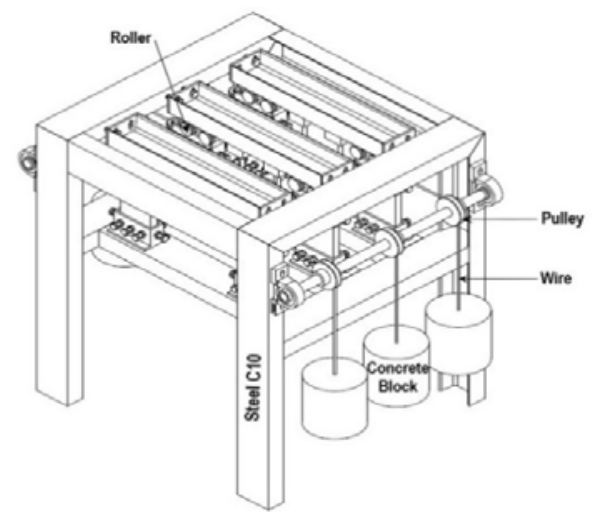

(a)

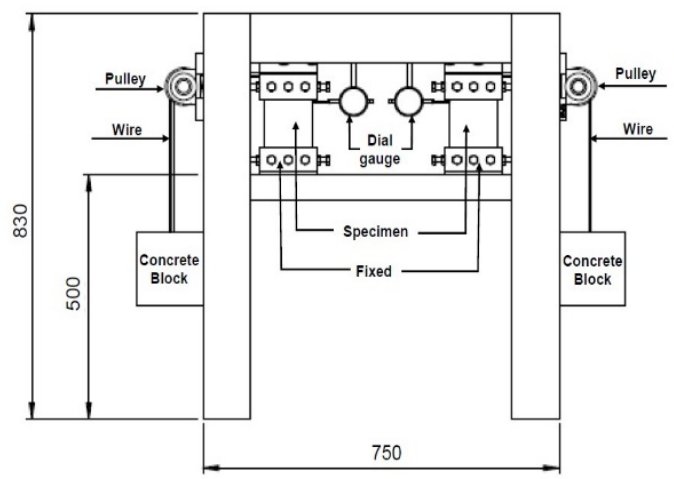

(b)

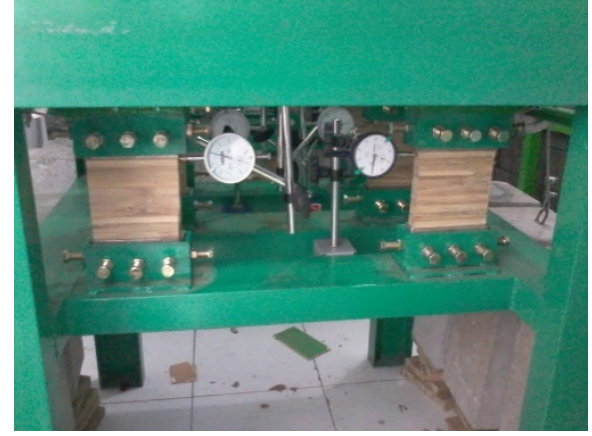

(c)

Fig. 5 Set-up creep shear deformation test (a) 3D view (b) Side view (unit in $\mathrm{mm}$ ) (c) photograph

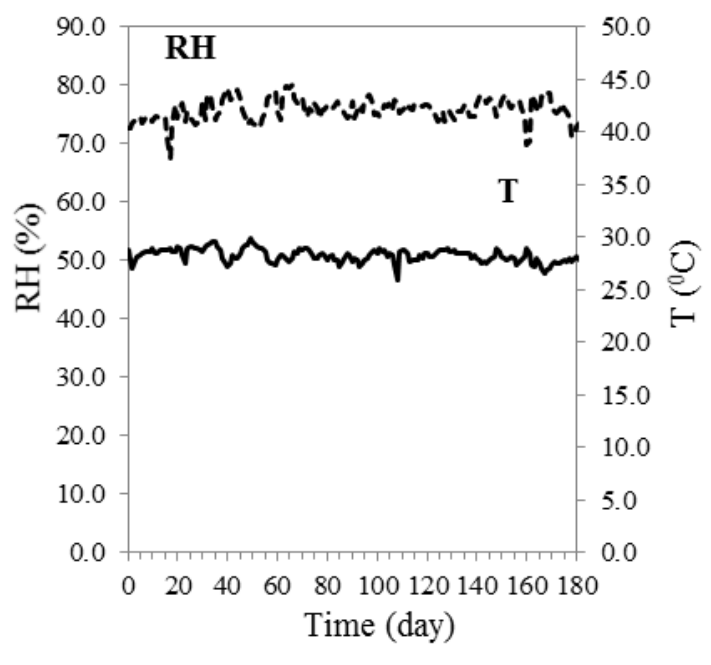

Fig.6 Temperature (T) and Relative Humidity (RH) in the creep room test

\section{RESULTS AND DISCUSSION}

\subsection{Creep Shear}

The result of the creep shear deformation and the strain of the three load level $20 \%, 30 \%$, and $40 \%$ according to the average of six replicate specimens of glued-laminated bamboo are presented in Fig. 7 and Fig. 8.

According to the Fig. 7 and Fig. 8, it can be seen that the instantaneous or elastic shear deformation and strain at load level 20\%, 30\%, $40 \%$ of glued-laminated bamboo increases 0.291 $\mathrm{mm}, 0.387 \mathrm{~mm}, 1.206 \mathrm{~mm}$ and $0.00291 \mu \mathrm{s}$, $0.00387 \mu \mathrm{s}, 0.01206 \mu \mathrm{s}$, respectively. After the elastic shear deformation and strain occurs, the shear strain tends to increase, although on certain days it has decreased due to the mechano-sorptive effect caused by fluctuating the Relative Humidity (RH) in the creep test room. However, the changing is not too significant. Until 180 days of creep shear deformation and shear strain at load 
levels of $20 \%, 30 \%$ and $40 \%$ were $1.024 \mathrm{~mm}$, $1.173 \mathrm{~mm}, 2.311 \mathrm{~mm}$ and $0.01024 \mu \mathrm{s}, 0.01173 \mu \mathrm{s}$, $0.02311 \mu \mathrm{s}$, respectively. Fig. 8 also shows that at the level of $20 \%$ and $30 \%$, the strain that occurred was relatively similar. In contrast to deformation and strain at $40 \%$ load level, where the deformation and strain that occur was greater than the two other levels of the loading.

By using curve fitting Buger model, the graph can show the primary and secondary creep stage $[12,21-22]$. The primary creep stage at the load level of $20 \%$, $30 \%$ and $40 \%$ was approximately for 15,18 and 35 days, respectively. Futhermore, the secondary creep stage was continued until 180 days. This means that the load level affected the primary and secondary creep stage.

\subsection{Creep Shear}

The creep rate was obtained from the deformation difference at time $\mathrm{t}$ with the previous deformation over time difference $(\Delta \delta / \Delta t)$ on the Burger model. The analysis results were shown in Fig. 9.

According to the Fig. 9, it appears that the load level also affected the initial creep shear rate of the glued-laminated bamboo, the greater the load level, the greater the tendency of the creep rate. At the load level of $30 \%$ and $40 \%$, the initial creep rate was almost the same, that was $0.0012 \mu \mathrm{s} /$ day and $0.0010 \mu \mathrm{s} /$ day, greater than the initial creep rate of the $20 \%$ load level that was $0.0006 \mu \mathrm{s} /$ day. For all load levels, the creep rate subsequently decreased as the time increased. The creep shear rates for load levels of $20 \%$ and $30 \%$, tends to be constant approximately on 20 and 30 days, while for the load level of $40 \%$ in 45 days.

\subsection{Relative Creep Shear}

Compared to the experimental data in the previous testing or researchs, it is easier if the creep test data is defined by the relative creep CR [22], where CR is the ratio between the difference in strain at a certain time $\gamma(\mathrm{t})$ to the instantaneous or elastic elastic strain $\left(\gamma_{0}\right)$ subtracting $\gamma_{0}$.

The graph of the relative creep shear vs time of glued-laminated bamboo is shown in Fig. 10. Furthermore, the data is performed by curve fitting by using the Burger and Power Law model, to predict the relative creep for structures under longterm constant shear load.

Based on Fig. 10, the graph of the average relative relationship (CR) of glued-lamination bamboo until 180 days is 1.882 lower than 2 (creep factor) according to the ASTM 6815 [24].

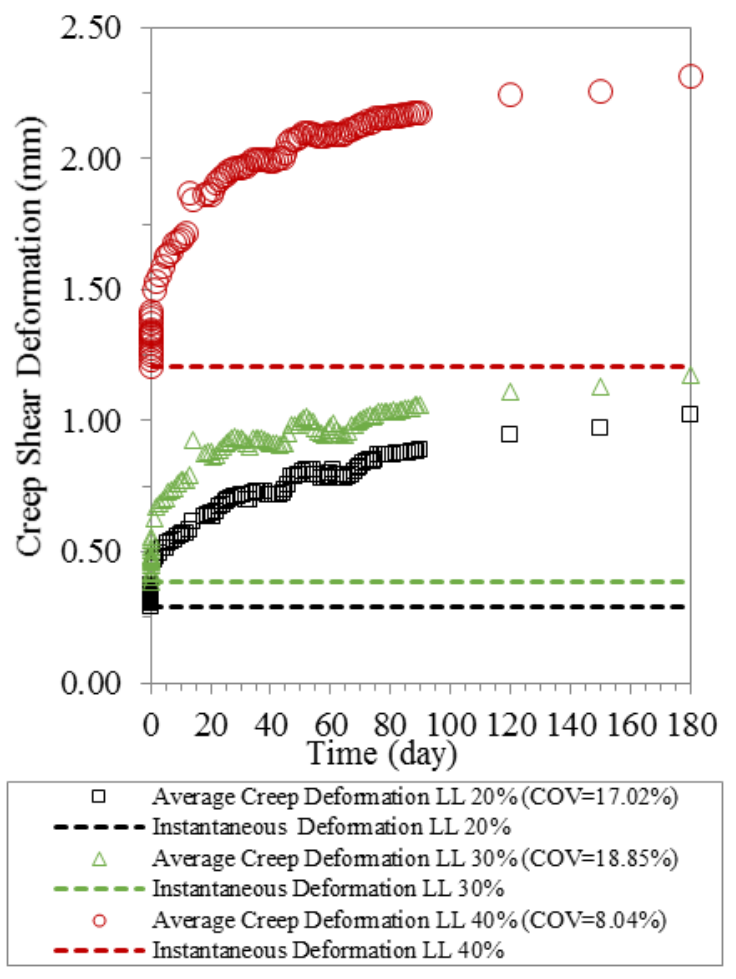

Fig.7 Creep shear deformation of glued-laminated bamboo
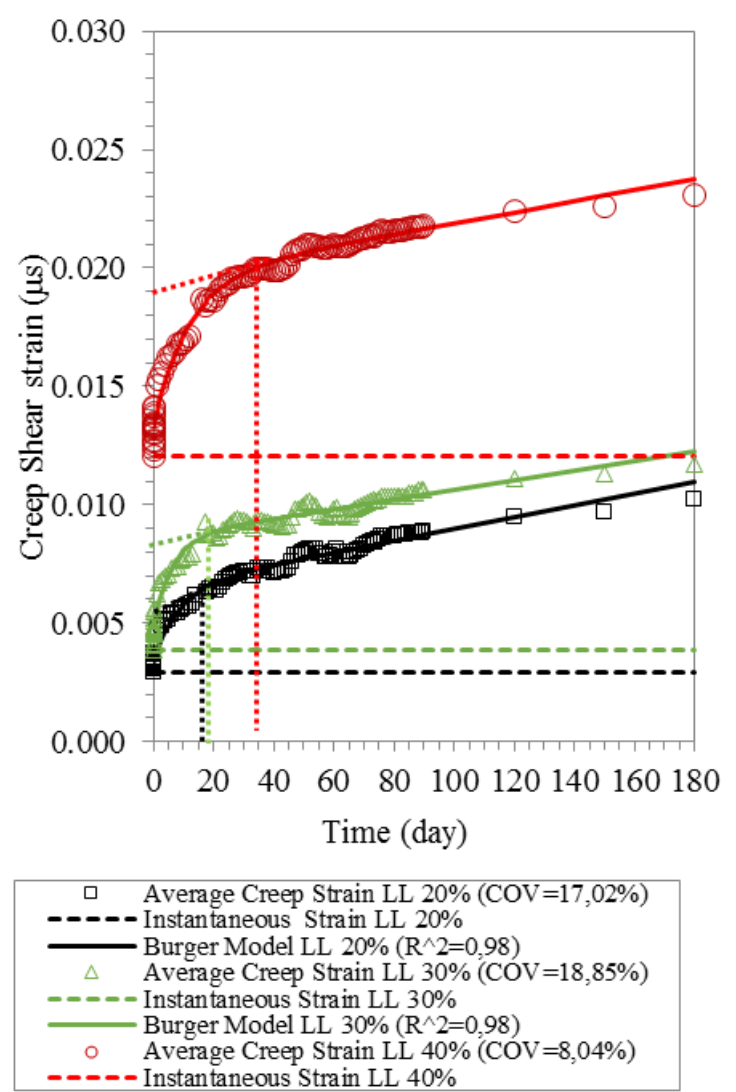

Fig.8 Creep shear strain of glued-laminated bamboo 


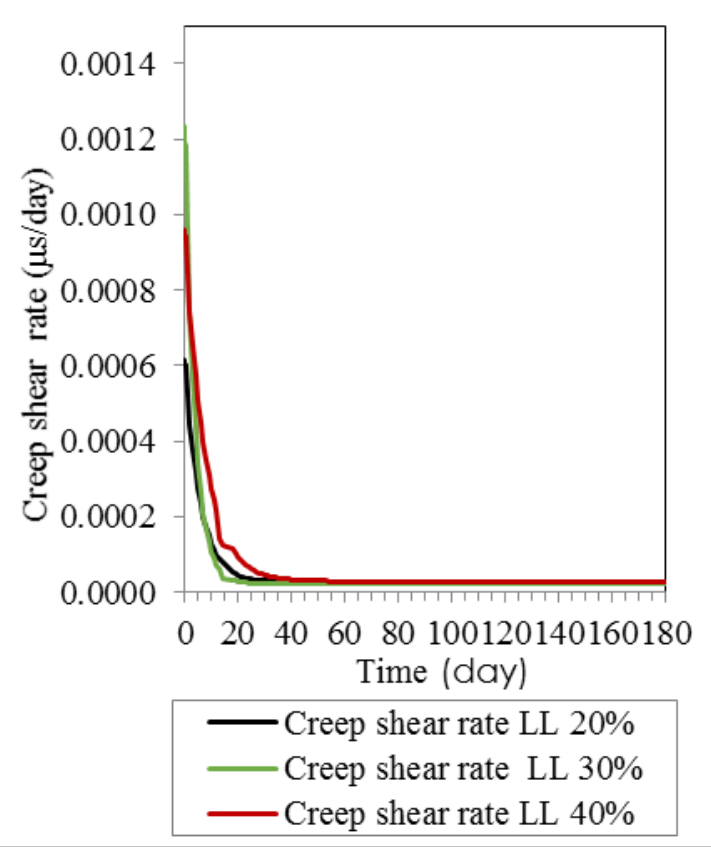

Fig.9 Creep shear rate of glued-laminated bamboo

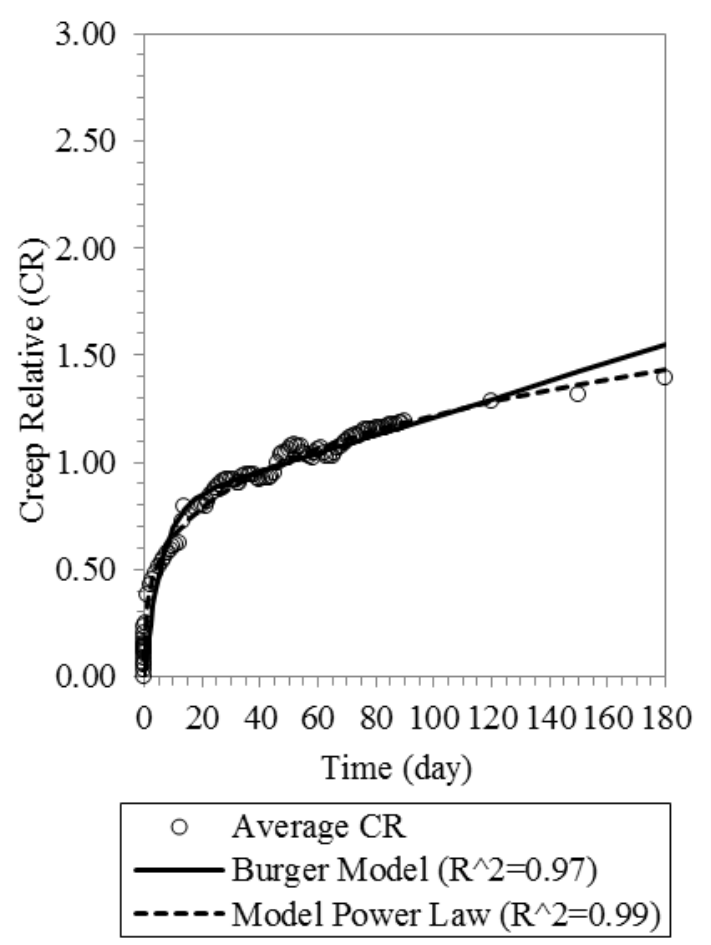

Fig.10 Relative creep shear of glued-laminated bamboo

\subsection{Relative Creep Shear}

The shear creep parameter was obtained from curve fitting using the Burger and Power Law model equation of the average total shear strain creep test data for 180 days as shown in Fig. 11 and the the results viscoelastic creep shear parameters can be seen in Table 1 .
Table 1 Parameters creep shear of glued-laminated bamboo

\begin{tabular}{cccc}
\hline Parameters & Unit & $\begin{array}{c}\text { Burger } \\
\text { Model }\end{array}$ & $\begin{array}{c}\text { Power } \\
\text { Law } \\
\text { Model }\end{array}$ \\
\hline $\mathrm{G}_{1}$ & $\mathrm{MPa}$ & 17.188 & - \\
$\mathrm{G}_{2}$ & $\mathrm{MPa}$ & 44.335 & - \\
$\eta_{1}$ & $\mathrm{MPa} /$ day & 8736.334 & - \\
$\eta_{2}$ & $\mathrm{MPa} /$ day & 863.333 & - \\
$\mathrm{A}$ & - & & $7.09 \times 10^{-4}$ \\
$\mathrm{~m}$ & - & & 0.091 \\
$\mathrm{n}$ & - & & -0.728 \\
\hline
\end{tabular}

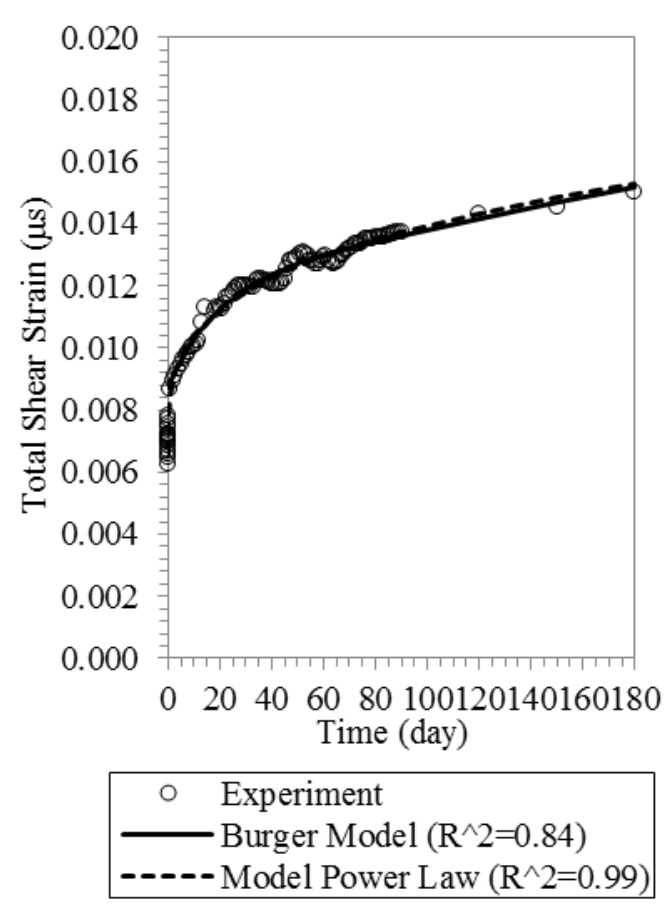

Fig.11 Curve fitting total shear strain Burger and Power Law model of glued-laminated bamboo

The parameter $G_{1}$ is Maxwell shear modulus, which can show elastic deformation behavior and can be used to predict shear modulus of gluedlaminated bamboo. The parameter $\mathrm{G}_{2}$ is the Kelvin shear modulus, $\eta_{1}$ is the Maxwell dashpot viscosity constant and $\eta_{2}$ is the Kelvin dashpot viscosity constant. The $\mathrm{G}_{1}$ value of the analysis result was $17.188 \mathrm{MPa}$, almost the same as the value of the shear modulus from the short term shear deformation capacity test which was 17.187 $\mathrm{MPa}$. The value of $\mathrm{G}_{2}$ reached a value of 44.335 MPa more than $G_{1}$. This $G_{2}$ parameter is related to retardation time creep. Meanwhile, if the parameter $\eta_{1}$ divided by $G_{1}\left(\tau_{1}=\eta_{1} / G_{1}\right)$, it can be used to predict relaxation time.

Likewise with the Power Law model, it has been successfully used to obtain the gluedlaminated bamboo creep parameters (see Table 1). The parameter A determines the creep deformation 
as a whole, while $\mathrm{m}$ and $\mathrm{n}$ related curvature of curve and explains the creep rate. From Table 1, can be seen value $\mathrm{A}, \mathrm{m}, \mathrm{n}$ are $7.09 \times 10^{-4}, 0.091$, 0.728 respectively.

The viscoelastic parameters of the creep shear test can also be used to predict the creep behavior of glued-laminated bamboo structure elements under constant long-term shear load, such as beams with torsional loads, connection plates and others.

\section{CONCLUSION}

Creep shear behavior of glued-laminated bamboo was investigated in the creep test room to the different load level 20\%, 30\% 40\%, the following conclusions could be made from the results and discussions presented above. Creep shear deformation, strain and rate increased when the load level increased. The Burger model was used to fit the creep data and then can be used for predicting primary and secondary creep stage. The Burger and Power model were successfully for predicting viscoelastic creep shear parameters.

\section{ACKNOWLEDGMENTS}

The authors would like to thank the Ministry of Research, Technology and the Higher Education Republic of Indonesia which has financial supporting in the Research Doctoral Dissertation. We also express gratitude to the Structure Laboratory of Departement of Civil and Environmental Engineering, Faculty of Engineering, Gadjah Mada University for supporting the devices.

\section{REFERENCES}

[1] van der Lugt, P., van den Dobbelsteen, A. A. J. F., Janssen, J. J. A., An Environmental, Economic and Practical Assessment of Bamboo as a Building Material for Supporting Structures. Contruction and Building Material xxx-xxxx, 2005, pp. 1-8.

[2] Bonilla, S. H., Guarnetti, R. L., Almeida, C. M. V. B., Giannetti, B. F., Sustainability assessment of a giant bamboo plantation in Brazil: Exploring the influence of labor, time, and space. Journal Cleaner Production 18(1), 2010, pp. 83-91.

[3] Masdar, A., Suhendro, B., Siswosukarto, S., Sulistyo, D., Determinant of Critical Distance of Bolt on Bamboo Connection. Jurnal Teknologi (Sciences \& Engineering) 69(6), 2014, pp. 111-115.
[4] Kamarudin, M., H., Mohd Suri Saringat, M., S., Sulaiman, N., H., The Study Of Mechanical Properties of Laminated Bamboo Strip (LBS) from Gigantochloa Levis Type Mixed with Epoxy. Jurnal Teknologi (Sciences \& Engineering) Vol 78, No 5-10, 2016, pp. 59-64.

[5] Sharma, B., Gatoo, A., Bock, Mulligan, H., M., Ramage, M., Engineered Bamboo: State of the Art, Proceeding of the Institution of Civil Engineers, 2014, pp. 66-73.

[6] Ni, L., Zhang, X., Liu, H., Sun, Z., Song, G., Yang, L., Jiang, Z., Manufacture and Mechanical Properties of Glued Bamboo Laminates, Glued Bamboo Lumber. BioResources 11(2), 2016, pp. 4459 - 4471.

[7] Janssen, J. J. A., Designing and Building with Bamboo. International Network for Bamboo and Rattan, 2000, ISBN 81-86247-46-7.

[8] Liese, W., Research on Bamboo. Wood Science and Technology. September. Volume 21. Issue 3, 1987, pp. 189-209.

[9] Xiao, Y., Zhou, Q., Shan, B., Design and Construction of Modern Bamboo Bridges. Journal of Bridge Engineering, Vol. 15, No. 5. September/Oktober, 2010, pp. 533-541.

[10] Xiao, Y., Li, L., Yang, R. Z., Long-Term Loading Behavior of a Full-Scale Glubam Bridge Model. Journal of Bridge Engineering. 19(9), 2014, pp. 1-7.

[11] Li, L., dan Xiao, Y., Creep Behavior of Glubam and CFRP-Enhanced Glubam Beams. Journal of Composite for Contruction. Juni 10, 2015, pp. 1-11.

[12] Gottron J., Harries K. A., \&Xu Q., Creep Behavior of Bamboo. Construction and Building Material, 2014, pp. 79-88,

[13] Awaludin A., Ngudiyono, Basuki A., Creep Properties of Walikukun (Schouthenia ovata) Timber Beams. Civil Engineering Dimension. 18(2), 2016, pp.78-84.

[14] Ngudiyono, Suhendro, B., Awaludin, A., Triwiyono, A., Review of creep modelling for predicting of long-term behavior of gluedlaminated bamboo structures. MATEC Web Conf. Volume 258, International Conference on Sustainable Civil Engineering Structures and Construction Materials (SCESCM 2018), 2019.

[15] Amino, Y., Bamboo-Precocious Wood Composite Beams: Bending Capacity for Long-Term Loading. Journal Bamboo and 
Rattan. Vol. 4. No. 1, 2005, pp. 55-70.

[16] Tsubaki, T., dan Nakano, T., Creep Behavior of Bamboo under Various Desorption. Holzforschung 64(4), 2010, pp. 489-493.

[17] Ma, X., Wang, G., Jiang, Z., Xian, Y., Li, H., Comparison of Bending Creep Behavior of Bamboo-Based Composites Manufactured by Two Types of Stacking Sequences. BioResources 9 (3), 2014, pp. 5461-5472.

[18] Ma, X., Liu, X., Jiang, Z., Fei, B., Wang, G., Flexural Creep Behavior of Bamboo Culm (Phyllostachys pubescens) in Its Radial Gauge Direction. Journal Wood Science, 2016.

[19] Ma, X., Shi, S. Q., Wang, G., Fei, B., Jiang, Z., Long creep-recovery behavior of bamboobased products. Journal of Wood Science, 2017.

[20] Ounjaijom, T., dan Rangsri, W., Numerical and Experimental Study of the Transverse Creep-Recovery Behavior of Bamboo Culm (Dendracalamus hamiltonii), Walailak Journal Science \& Technology. 13(4), 2016, pp. 615 629.
[21] Findley, M. N., Lai, J. S., Onaran, K., Creep and Relaxation of Nonlinear Viscoelastic Material with Introduction to Linear Viscoelastic, Dover Publication, Inc., New York, 1976.

[22] Bodig, J. dan Jayne, B. A., Mechanical of Wood and Wood Composites, Kriger Publishing Company, Malabar Florida, 1982.

[23] Guo, D. L., Chen, B. S., Liou, N. S., Investigating Full-Field Deformation of Planar Soft Tissue Under Simple-Shear Test. Journal of Biomechanics 40, 2007, pp. 165 1170

[24] ASTM D6815, Standart Specification for Evaluation of Duration of Load and Creep Effect of Wood and Wood-Based Product, Annual Book of ASTM Standart, Vol. 4, No. 10, West Conshojocken, PA, 2002.

[25] Abaqus Version 6.4, Abaqus/CAE User's Manual, Pawtucket, Rhode Island, USA, 2003.

Copyright (C) Int. J. of GEOMATE. All rights reserved, including the making of copies unless permission is obtained from the copyright proprietors. 